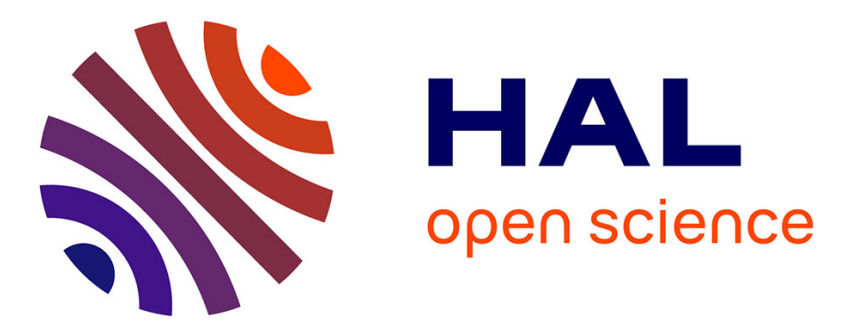

\title{
Degradation of paracetamol by catalytic wet air oxidation and sequential adsorption - Catalytic wet air oxidation on activated carbons
}

Isariebel Quesada-Peñate, Carine Julcour-Lebigue, Ulises J. Jauregui-Haza, Anne-Marie Wilhelm, Henri Delmas

\section{To cite this version:}

Isariebel Quesada-Peñate, Carine Julcour-Lebigue, Ulises J. Jauregui-Haza, Anne-Marie Wilhelm, Henri Delmas. Degradation of paracetamol by catalytic wet air oxidation and sequential adsorption Catalytic wet air oxidation on activated carbons. Journal of Hazardous Materials, 2012, vol. 221-222, pp. 131-138. 10.1016/j.jhazmat.2012.04.021 . hal-00738515

\section{HAL Id: hal-00738515 https://hal.science/hal-00738515}

Submitted on 4 Oct 2012

HAL is a multi-disciplinary open access archive for the deposit and dissemination of scientific research documents, whether they are published or not. The documents may come from teaching and research institutions in France or abroad, or from public or private research centers.
L'archive ouverte pluridisciplinaire HAL, est destinée au dépôt et à la diffusion de documents scientifiques de niveau recherche, publiés ou non, émanant des établissements d'enseignement et de recherche français ou étrangers, des laboratoires publics ou privés. 


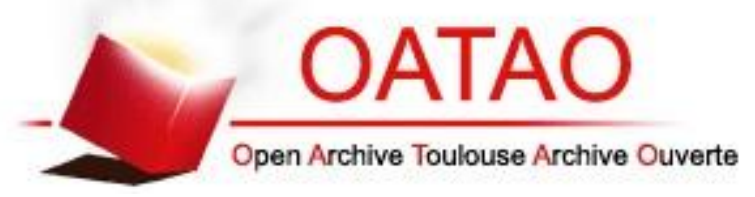

\section{Open Archive Toulouse Archive Ouverte (OATAO)}

OATAO is an open access repository that collects the work of Toulouse researchers and makes it freely available over the web where possible.

This is an author-deposited version published in: http://oatao.univ-toulouse.fr/ Eprints ID: 6293

To link to this article: doi: 10.1016/j.jhazmat.2012.04.021

URL: http://dx.doi.org/10.1016/j.jhazmat.2012.04.021

To cite this version: Quesada-Peñate, Isariebel and Julcour-Lebigue, Carine and Jauregui-Haza, Ulises J. and Wilhelm, Anne-Marie and Delmas, Henri Degradation of paracetamol by catalytic wet air oxidation and sequential adsorption - Catalytic wet air oxidation on activated carbons. (2012) Journal of Hazardous Materials, vol. 221-222 . pp. 131138. ISSN 0304-3894

Any correspondence concerning this service should be sent to the repository administrator: staff-oatao@listes.diff.inp-toulouse.fr 


\title{
Degradation of paracetamol by catalytic wet air oxidation and sequential adsorption - catalytic wet air oxidation on activated carbons
}

\author{
I. Quesada-Peñate ${ }^{\mathrm{a}, \mathrm{b}}$, C. Julcour-Lebigue ${ }^{\mathrm{a}, \mathrm{b}^{*}}$, U. J. Jáuregui-Haza ${ }^{\mathrm{c}}$, A. M. Wilhelm ${ }^{\mathrm{a}, \mathrm{b}, \dagger}$, H. Delmas ${ }^{\mathrm{a}, \mathrm{b}}$ \\ ${ }^{a}$ Université de Toulouse, INPT, UPS, Laboratoire de Génie Chimique, 4, Allée Emile Monso, F- \\ 31432 Toulouse, France \\ ${ }^{\mathrm{b}} \mathrm{CNRS}$, Laboratoire de Génie Chimique, F-31432 Toulouse, France \\ 'Instituto Superior de Tecnologías y Ciencias Aplicadas, Ave. Salvador Allende y Luaces, Habana, \\ Cuba \\ *Corresponding author. Tel.: +33532343709; fax: +33532343600. E-mail address: \\ carine.julcour@ensiacet.fr
}

\begin{abstract}
The concern about the fate of pharmaceutical products has raised owing to the increasing contamination of rivers, lakes and groundwater. The aim of this paper is to evaluate two different processes for paracetamol removal. The catalytic wet air oxidation (CWAO) of paracetamol on activated carbon was investigated both as a water treatment technique using an autoclave reactor and as a regenerative treatment of the carbon after adsorption in a sequential fixed bed process. Three activated carbons (ACs) from different source materials were used as catalysts: two microporous basic ACs (S23 and C1) and a meso- and micro-porous acidic one (L27). During the first CWAO experiment the adsorption capacity and catalytic performance of fresh S23 and C1 were higher than those of fresh L27 despite its higher surface area. This situation changed after AC reuse, as finally $\mathrm{L} 27$ gave the best results after five CWAO cycles. Respirometry tests with activated sludge revealed that in the studied conditions the use of CWAO enhanced the aerobic biodegradability of the effluent. In the ADOX process L27 also showed better oxidation performances and regeneration efficiency. This different ageing was examined through AC physicochemical properties.
\end{abstract}

Keywords: Catalytic oxidation, Adsorption, Activated carbon, Biodegradability, Paracetamol

\footnotetext{
${ }^{\dagger}$ Deceased on $1^{\text {st }}$ June 2009
} 


\section{Introduction}

Numerous studies around the world have demonstrated the presence of pharmaceutical compounds in waterways [1-7], as they are found resistant to biological degradation and usually escape conventional WWTPs [8]. In particular, paracetamol (N-acetyl-4-aminophenol), a common analgesic and anti-inflammatory used for humans and animals, has been reported as the pharmaceutical compound present in largest concentration in French rivers [9].

Considering the potential impacts of pharmaceutical products on environment and human health, additional treatments have to be applied to drastically reduce the load of such molecules in discharged effluents and best achieve non-detectable concentrations.

Several technologies have already proven to be effective for this purpose. Among the most cited appear activated carbon adsorption [10-14], as well as advanced oxidation processes like ultrasound [15-17], ozonation [18-21], photocatalysis [22-23], (photo)Fenton oxidation [24-26], and hybrid configurations [27-29]. More examples can be found in the review of Klavarioti et al. [8]. On the other hand, catalytic wet air oxidation $(\mathrm{CWAO})$ - in particular with cheap activated carbon (AC) has been extensively studied for the degradation of organics compounds [30-33], but not yet applied to pharmaceutical products. Recently, an hybrid process (AD-OX) of classical adsorption of pollutants on a fixed bed of activated carbon followed by batch wet catalytic oxidation at higher temperature and pressure on the same bed of $\mathrm{AC}$, which is then regenerated in situ, has been also evaluated for the remediation of phenols [34-36]. The basic idea is to take advantage of both operations: 1) efficient and cheap water purification at room temperature by adsorption, 2) effective pollutant degradation by catalytic air oxidation achieving simultaneously AC regeneration for the next adsorption.

Despite the oxidative treatments have to be evaluated in the view of an integrated process with biological degradation (usually as a pre-treatment), only a few studies have assessed the biodegradability, toxicity or inhibitory effects of the intermediates resulting from partial oxidation, [33, 37-41]. Chemical analysis of a limited suite of compounds does not assess the potential biological adverse effects of the wastewater as it does not reflect possible cumulative and interaction effects. Therefore bioassays have to be used as complementary monitoring tools. To this end, respirometry has emerged as a particularly significant analysis because the oxygen uptake rate represents a direct measurement of the correct activity and viability of the microorganisms present in an aerobic activated sludge [42].

In this context, the present paper has two objectives related to the remediation of paracetamol: first, to study the CWAO of the molecule on different activated carbons, including the biodegradability assessment of the oxidation effluent; second, to study the feasibility of the sequential adsorptionoxidation process in which water quality is provided by the adsorption step.

\section{Materials and methods}

\subsection{Physico-chemical characterization of activated carbons}

Three ACs were used in both the batch autoclave and fixed bed experiments: carbon L27 from wood, S23 from coconut shell (Pica, Veolia group) and C1 from casuarina (CIPIMM, Havana).

The surface area and pore volume of the carbons were measured from nitrogen adsorption isotherms at 77K, using an ASAP 2010 analyzer (Micromeritics). Specific surface area was calculated from BET plot for relative pressures between 0.01 and 0.2.

Thermogravimetric analysis (TGA) was performed under nitrogen flow from room temperature to $700^{\circ} \mathrm{C}$ at a heating rate of $10^{\circ} \mathrm{C} / \mathrm{min}(\mathrm{Q} 600 \mathrm{SDT}$, TA Instrument) in order to compare the amount of functional groups on the three carbons.

Their acid/base properties were determined using the procedure proposed by Boehm [43]. $70 \mathrm{~mL}$ of $0.05 \mathrm{~N} \mathrm{NaOH}$ or $0.05 \mathrm{~N} \mathrm{HCl}$ solutions were added to $1 \mathrm{~g}$ of $\mathrm{AC}$ in a glass bottle. The bottles were degassed under $\mathrm{N}_{2}$, sealed and let to equilibrate for three days in a rotatory shaker. Then, the carbon 
was separated from the solution and $3 \mathrm{~mL}$ of each filtrate were titrated (DL 50, Mettler Toledo) using $\mathrm{HCl}$ or $\mathrm{NaOH}(0.05 \mathrm{~N})$, as required. Each experiment was triplicated under identical conditions. The $\mathrm{pH}$ at the point of zero charge $\left(\mathrm{pH}_{\mathrm{PZC}}\right)$ was measured by the $\mathrm{pH}$ drift method. $0.1 \mathrm{~g}$ of carbon was added to $20 \mathrm{~mL}$ of $0.1 \mathrm{~mol} / \mathrm{L} \mathrm{NaCl}$ solution, whose initial $\mathrm{pH}$ was adjusted with $\mathrm{NaOH}$ or $\mathrm{HCl}$. The containers were flushed with $\mathrm{N}_{2}$, sealed and placed in a shaker for $24 \mathrm{~h}$, after which the $\mathrm{pH}$ was measured. The PZC occurred when there was no change in the $\mathrm{pH}$ after contact with the carbon.

Elemental analysis of the ACs was carried out using Thermo Finnigan Flash EA111 for CHNSO and lixiviation/ICP-AES (Jobin Yvon - Ultima 2R) for metals.

The room temperature adsorption isotherms of paracetamol were also measured on the three carbons: $100 \mathrm{~mL}$ of a paracetamol solution (initial concentration between $0.041 \mathrm{~g} / \mathrm{L}$ and $1.3 \mathrm{~g} / \mathrm{L}$ ) and a fixed amount of activated carbon $(0.1 \mathrm{~g}$ for L27 and $0.05 \mathrm{~g}$ for S23 and C1) were mixed during 24 hours in a thermostated bath at $25^{\circ} \mathrm{C}$. The equilibrium concentration of paracetamol on solid phase was calculated from initial and final concentrations in aqueous solution measured by liquid chromatography (see $\S 2.2 .1 .2$.). Each experiment was repeated threefold under identical conditions. Five different models were used to fit single component isotherms and the best one was selected using statistical regression criteria as described by Quesada et al. [14].

\subsection{Experimental set-ups and analytical procedures}

\subsubsection{CWAO experiments}

The first step of the study was the selection of suitable oxidation catalysts among the three ACs using a batch stirred autoclave (Parr Instruments).

\subsubsection{Operating conditions}

In a typical experimental run, $200 \mathrm{~mL}$ of $1 \mathrm{~g} / \mathrm{L}$ paracetamol aqueous solution and $1 \mathrm{~g}$ of $\mathrm{AC}$ were added to the reactor, operating at $150^{\circ} \mathrm{C}$ and 3.2 bar of oxygen partial pressure (total pressure 20 bar). The experiments were performed batchwise for the liquid phase and were continuous for air, circulating with a flow rate of $60 \mathrm{~L} / \mathrm{h} \mathrm{STP}$ to ensure constant oxygen pressure. Prior to oxidation reactions, the ACs $(0.8-1.0 \mathrm{~mm})$ were equilibrated with paracetamol at $150^{\circ} \mathrm{C}$ under nitrogen atmosphere. The stirrer speed was set at $800 \mathrm{rpm}$ to avoid catalyst attrition and prevent external mass transfer limitations. Five oxidation cycles were completed in each case in order to evaluate the catalyst efficiency and the biodegradability of resulting effluents.

\subsubsection{Chemical analyses}

Liquid samples were characterized using a HPLC equipped with a UV/Vis detector (Varian ProStar 310). Paracetamol was separated from oxidation intermediates on a Prontosil $\mathrm{C}_{18}$ reversed phase column using a 90:10 mixture of acidified water $(\mathrm{pH} 2.2)$ and acetonitrile as isocratic mobile phase (flow rate of $0.25 \mathrm{~mL} \cdot \mathrm{min}^{-1}$ ). The detection of the compound was achieved at a wavelength of 254 nm.

The closed reflux colorimetric method was used to determine COD values. $2 \mathrm{~mL}$ of sample, diluted or not, was introduced into a commercially available digestion tube and the mixture was then heated $120 \mathrm{~min}$ at $150^{\circ} \mathrm{C}$. The amount of oxidizing agent reduced was subsequently determined colorimetrically using a UV spectrophotometer (Hach Odyssey DR/2500) operating at $620 \mathrm{~nm}$ and expressed as COD.

\subsubsection{Bioassays}

Respirometry tests were performed with activated sludge to assess the aerobic biodegradability and the possible inhibitory effect of paracetamol and its oxidation products. The apparatus consisted in a glass respirometry cell maintained at $26^{\circ} \mathrm{C}$. Dissolved oxygen concentration and temperature were monitored continuously throughout the experiments. The respirometer was inoculated with biomass from the aeration tank of the Brax wastewater treatment plant (Toulouse, France). Sodium acetate 
was used as a biodegradable substrate and added before and after the injection of paracetamol or final effluents from batch CWAO. The procedure was as follows: a pulse of $98 \mathrm{mg} \mathrm{COD} / \mathrm{L}$ of sodium acetate was first added. After the control substrate was consumed, a pulse of effluent with equivalent COD was injected. The last step consisted in the addition of the same pulse of acetate as in the first run.

From integration of the Oxygen Uptake Rate (OUR) profiles, oxygen consumptions (OC) obtained with sodium acetate at the first run (sdt1) and with reaction mixture were compared. A biodegradability index was subsequently calculated according to equation 1 . The toxicity of the effluent (equation 2) was determined from the maximum values of the OUR curves $\left(\mathrm{OUR}_{\max }\right)$ corresponding to the two additions of sodium acetate (std1 and std2).

Biodeg radability index $(\%)=\left(1-\frac{\mathrm{OC}_{\mathrm{std} 1}-\mathrm{OC}_{\mathrm{effluent}}}{\mathrm{OC}_{\mathrm{std} 1}}\right) \times 100$
Toxicity index $(\%)=\left(\frac{\mathrm{OUR}_{\mathrm{max}, \mathrm{std} 1}-\mathrm{OUR}_{\max , \mathrm{std} 2}}{\mathrm{OUR}_{\max , \mathrm{std} 1}}\right) \times 100$

\subsubsection{AD-OX fixed bed process}

A sequential process consisting in continuous adsorption on $\mathrm{AC}$ followed by batch CWAO was conducted on the same fixed bed set-up, oxidation achieving AC regeneration in mild conditions. The experimental setup (Figure 1) was previously described by Suwanprasop et al. [44]. The reactor (1.2 m high, $2.54 \mathrm{~cm}$ internal diameter) was successively packed with $168 \mathrm{~g}$ of L27 and $340 \mathrm{~g}$ of S23 AC particles (1.25-1.40 mm sieved fraction).

The adsorption step was operated at ambient conditions $\left(25^{\circ} \mathrm{C}\right.$, atmospheric pressure). Solutions of $1 \mathrm{~g} / \mathrm{L}$ and $2 \mathrm{~g} / \mathrm{L}$ of paracetamol for L27 and S23 respectively were continuously introduced into the column by a dosing pump.

The same pump was used to feed the column by recycling the reaction mixture from a pressurized tank during the oxidative regeneration step. The wall temperature was here set to $150{ }^{\circ} \mathrm{C}$, and the oxygen partial pressure $\left(\mathrm{P}_{\mathrm{O} 2}\right)$ was adjusted to 3.2 bar. The gas flow rate $\left(50: 50 \mathrm{O}_{2}: \mathrm{N}_{2}\right.$ mixture $)$ was $100 \mathrm{~L} / \mathrm{h}$ STP and the liquid flow rate was $2 \mathrm{~L} / \mathrm{h}$. Gas and liquid circulated cocurrently upward through the fixed bed. Three adsorption-oxidation cycles were completed for each AC. Liquid samples were characterized using the chemical analyses described in $§ 2.2 .1 .2$.

\section{Results and discussion}

\subsection{Textural, chemical and adsorptive properties of fresh activated carbons}

The physico-chemical properties of the carbons are listed in Table 1. Among the investigated ACs, L27 has the highest surface area. S23 and C1 have very similar surface area but S23 is essentially a microporous carbon. The quantification of the carbon surface groups by Boehm titration reveals that L27 has also the greatest content of acidic and total surface groups. On the other hand, C1 has the greatest content of basic groups. TGA spectra confirm the results of Boehm titration with an increasing weight loss from $\mathrm{S} 23$ to $\mathrm{C} 1$ and from $\mathrm{C} 1$ to $\mathrm{L} 27$. In accordance with previous results, L27 is also found to have the lowest $\mathrm{pH}_{\mathrm{PZC}}$ and the highest oxygen content. Finally, the elemental analysis shows that all ACs have low metal contents, with a larger amount of Fe for $\mathrm{C} 1$.

Figure 2 compares the paracetamol isotherms measured on the three carbons (with corresponding best fit adsorption model), showing a lower capacity for L27 despite a higher surface area. This conclusion is in accordance with those reported for phenol and some aromatic molecules for which a clear decrease in adsorption capacity is found when there are more acidic groups on the carbon surface [14, 45-46]. An accepted mechanism for this phenomenon is the formation of water clusters 
through $\mathrm{H}$-bonding with acidic (carboxylic) surface groups, which reduces AC adsorption capacity [46].

\subsection{CWAO of paracetamol: activated carbon screening and biodegradability assessment}

\subsubsection{Initial performance of the carbons}

Figure 3 shows the time concentration profiles during preliminary adsorption and oxidation using fresh ACs.

The adsorption equilibrium at $150^{\circ} \mathrm{C}$ was approximately reached after 2 hours when $86.7,134.5$ and $126.1 \mathrm{mg}$ of paracetamol per $\mathrm{g}$ of $\mathrm{AC}$ were adsorbed on L27, S23 and C1 respectively. The adsorption results at $150^{\circ} \mathrm{C}$ were in agreement with the isotherms obtained at $25^{\circ} \mathrm{C}$, lower paracetamol uptake being observed for the acidic carbon.

Then, after adsorption equilibrium under nitrogen, the CWAO reaction was started. The highest initial oxidation rate was obtained with fresh $\mathrm{C} 1$ carbon $(3 \mathrm{mg} / \mathrm{min})$ and the lowest one with $\mathrm{L} 27$ $(1.6 \mathrm{mg} / \mathrm{min})$.

Table 2 shows the comparison of paracetamol adsorption, conversion and COD removal for the three fresh ACs. It is obvious that although a high conversion was obtained for all the ACs, the presence of acidic groups on L27 surface affected both the adsorption and the COD removal.

\subsubsection{Catalytic stability upon recycling}

The stability of AC catalytic activity was tested by completing a series of five consecutive experiments (Figures 4a and 4b). For S23 and C1 a large decrease of paracetamol conversion was observed after two oxidations, but it was rather constant for the last three cycles. For L27, paracetamol conversion was quite stable and only a slightly decrease was observed in the last cycle (Figure 4a). After five cycles the COD removal was only of $20 \%$ or less for all the three ACs (Figure 4b).

\subsubsection{Characterization of the spent carbons}

At the end of the experimental series, the analysis of aged ACs (Table 3) showed that the BET surface area decreased by a factor of 3, 26 and 14 for L27, S23 and C1 respectively. Pore volume decreased too. The observed catalyst deactivation can thus be related to the loss of surface area, especially strong for the basic and microporous carbon.

Such a change in AC porous structure has already been reported during the CWAO of phenol and some of its derivatives, which has been attributed to the deposition of condensation products, blocking the access to micropores [31-32,44].

Thermogravimetric analysis also reveals a higher weight loss between $200^{\circ} \mathrm{C}$ and $700^{\circ} \mathrm{C}$ for all spent carbons (Table 3) as compared to fresh ones (Table 1). This increase should correspond not only to the calcination of new surface groups, but also probably to the decomposition of these chemisorbed oligomers formed by oxidative coupling reactions. Such a phenomenon is found to be hindered by the presence of acidic surface groups [33], which might explain this better stability of L27.

\subsubsection{Biodegradability assessment}

In order to compare the biodegradability of paracetamol and that of the effluent from batch oxidation on L27, a pulse equivalent to $98 \mathrm{mg} \mathrm{COD} / \mathrm{L}$ of each was successively introduced into the respirometer (this COD value corresponds to $50 \mathrm{mg} / \mathrm{L}$ of paracetamol). Figure 5 shows the OUR profiles obtained for each experiment. After paracetamol had been added to the system (Figure 5a), the oxygen consumption corresponding to sodium acetate was unchanged compared to the first run $(19 \mathrm{mg} / \mathrm{L})$. Same values of OUR $\max$ were also obtained for the two additions of control substrate. Those results indicate that up to $50 \mathrm{mg} / \mathrm{L}$, paracetamol is not toxic for the investigated biomass. On the other hand, the OUR profile corresponding to paracetamol is very flat, leading to an OC value 
equal to $2 \mathrm{mg} / \mathrm{L}$. From equation 1, short term biodegradability of paracetamol is then estimated at $10 \%$ relative to that of sodium acetate.

Figure $5 \mathrm{~b}$ exhibits a significant improvement of the biodegradability index by CWAO (B.I.=85\%). No sign of toxic or inhibitory effect is detected with this reaction mixture. Although a detailed study of the reaction intermediates is not presented in this paper, it is obvious that the by-products formed during the oxidation process are readily biodegradable substances.

\subsubsection{Evolution of paracetamol uptake during preliminary adsorption}

In order to evaluate the role of the adsorption capacity of the ACs on their catalytic performance and to select the most suitable activated carbons for the AD-OX process, the adsorbed amount of paracetamol at equilibrium after the preliminary adsorption step was calculated for each catalyst and each cycle (Figure 6).

The adsorption capacity of L27 was more stable and it was only reduced by a factor 1.5 after five cycles. On the opposite, for S23 and C1 ACs the adsorption capacity strongly diminished during four or five cycles. There is thus some correspondence between the catalyst activity and the adsorption capacity of the carbons as proved by the similarity of Figures $4 \mathrm{a}$ and 6 . This seems to apply not only for fresh carbons, but also during their recycling.

Based on this long term performance, L27 was readily selected for the AD-OX fixed bed process; S23 was also used as microporous catalyst for comparison purposes.

\subsection{Hybrid AD-OX process (fixed bed operation)}

\subsubsection{Room temperature adsorption step}

Contrary to an efficient application of the AD-OX sequential process for water treatment, the complete breakthrough curve was derived, in order to have a better knowledge of the adsorption behaviour of the carbons and to estimate regeneration efficiency by CWAO.

After the breakthrough, the storage tank connected to the reactor outlet was filled with $2 \mathrm{~L}$ of the paracetamol solution circulating through the fixed bed.

With L27 (Figure 7), equilibrium conditions could be achieved within one day: the adsorption capacity calculated by numerical integration of the first breakthrough curve $\left(385 \mathrm{mg} / \mathrm{g}_{\mathrm{AC}}\right)$ was comparable to that obtained from the isotherm. The difference (about 20\%) might be attributed to the flowing of water prior to paracetamol solution which might have slightly modified the carbon surface property.

After about 15 hours of batch oxidation to destroy absorbed pollutant, a $43 \%$ recovery of the initial adsorption capacity could be achieved for L27.

The next cycle gave reproducible breakthrough curve, which proved the activated carbon to be stabilized both as adsorbent and oxidation catalyst after first cycle. The analysis of spent AC also showed an important loss of surface area and microporous volume (by 84\%), even more than what was observed in the autoclave reactor despite a higher solid to liquid ratio.

The adsorption dynamics on fresh S23 (Figure 8) was rather different from that on L27. Only three fourth of the theoretical capacity of S23 was obtained after three days when outlet concentration already reached $95 \%$ of feed concentration. Moreover, adsorption being performed with stops during nights, the breakthrough curve of S23 showed a sharp decrease when starting solution feed again owing to the slow diffusion of the molecule inside the microporous structure of the carbon.

As expected, after 15 hours of oxidation, a lower recovery of the initial adsorption capacity was obtained for S23 (only 13\%).

However, as shown in the third experiment, increasing oxidation time could significantly improve regeneration yield (up to $39 \%$ after 30 hours of oxidation). After the successive cycles, the BET surface area of S23 was reduced by $87 \%$.

\subsubsection{Oxidation step}


Figure 9a compares for the two carbons the evolution of the normalized paracetamol concentration measured in the 2 liters of solution which are circulated through the bed during the first oxidation step. The experimental procedure included a heating period under nitrogen resulting in a preliminary significant desorption of the pollutant. Therefore the oxidation started with higher concentrations of paracetamol in the liquid phase than the respective feed concentrations during adsorption: 3753 and $5884 \mathrm{mg} / \mathrm{L}$ respectively for L27 and S23.

Although an initially faster decrease of paracetamol concentration was observed with S23, full conversion of the molecule was only achieved within 12 hours compared to 4 hours for L27. This was also in accordance with the CWAO results measured in batch autoclave, showing L27 to be less efficient during the first oxidation, but giving better results after five oxidation cycles.

More surprisingly, time-evolution of liquid phase COD, Figure 9b, exhibited a minimum, COD increasing after paracetamol was depleted. Such behaviour was not observed with phenol as the model pollutant and much lower solid to liquid ratio [47]. It would result from the slow desorption and slower degradation of oxidation intermediates, main part of the pollutant (more than 95\%) being originally adsorbed on AC in this high solid loading recycle reactor. Nevertheless the final COD in solution represented for L27 and S23 about 15 and 5\% respectively of the whole initial pollution.

\section{Conclusions}

A sequential adsorption-batch CWAO process was investigated for the treatment of a paracetamol solution. Three activated carbons were compared both as adsorbents and catalysts of CWAO for their own regeneration. The initial catalyst activity seemed to be tied to the adsorption capacity of the ACs. The reuse of catalyst in consecutive runs showed a rapid deterioration in both BET surface area and catalyst performance. This is due to the formation of oligomers irreversibly adsorbed on the AC surface and minimally oxidized, which block the access to the micropores, as confirmed by TGA before and after oxidation. This preliminary investigation allowed the selection of the acidic and mesoporous AC (L27) for the sequential AD-OX process in fixed bed reactor, due to better ageing and despite lower initial performances. Three successive AD-OX cycles with L27 were carried out showing quasi stabilisation between runs 3 and 2 after an initial strong adsorption loss.

\section{Nomenclature}

$\mathrm{q}_{\mathrm{e}} \quad$ amount of adsorbed compound at equilibrium per unit weight of adsorbent, $\mathrm{mg} / \mathrm{g}_{\mathrm{AC}}$

$\mathrm{C}_{\mathrm{e}} \quad$ concentration of adsorbate in aqueous phase at equilibrium, $\mathrm{mg} / \mathrm{L}$

COD chemical oxygen demand, $\mathrm{mg} / \mathrm{L}$

$\mathrm{T}$ temperature, ${ }^{\circ} \mathrm{C}$

$\mathrm{t}$ reaction time, $\mathrm{h}$

$\mathrm{C}_{0} \quad$ initial concentration of pollutant, $\mathrm{mg} / \mathrm{L}$

$\mathrm{w}_{\mathrm{AC}} \quad$ activated carbon weight, $\mathrm{g}$

$\mathrm{P}_{\mathrm{N} 2} \quad$ nitrogen partial pressure, bar

$\mathrm{P}_{\mathrm{O} 2} \quad$ oxygen partial pressure, bar

$\mathrm{C}_{\text {in }} \quad$ inlet concentration of pollutant, $\mathrm{mg} / \mathrm{L}$

$\mathrm{Q}_{\mathrm{L}} \quad$ liquid flow rate, $\mathrm{L} / \mathrm{h}$

$\mathrm{Q}_{\mathrm{G}} \quad$ gas flow rate (oxygen/nitrogen mixture), L/h STP

$\mathrm{C}_{0}$,ox $\quad$ initial concentration of pollutant prior oxidation, $\mathrm{mg} / \mathrm{L}$

$\mathrm{V}_{\mathrm{L}} \quad$ volume of liquid, $\mathrm{L}$

\section{Acknowledgements}

The authors express their gratitude to the European Community through ALFA and $6^{\text {th }}$ Framework Programmes (6 ${ }^{\text {th }}$ FP "REMOVALS"), the Embassy of France in Cuba, Agence Nationale de la Recherche (Precodd "PHARE" project) and INP-ENSIACET for financial support. They also thank PICA (Veolia group) for supplying S23 and L27 ACs, CIPIMM for supplying C1 AC, L. Le Coq, C. Gerente (GEPEA, Nantes), C. Rouch, M. Auriol and S. Mouysset (SAP, LGC Toulouse) for AC characterization, A. Zarragoitia and C. Albasi (BioSYM, LGC Toulouse) for respirometry tests. 


\section{References}

[1] T.A. Ternes, Occurrence of drugs in German sewage treatment plants and rivers, Water Res. 32 (1998) 3245-3260.

[2] A. Alighardashi, M.N. Pons, O. Potier, Occurrence and fate of pharmaceutical substances in urban wastewater, a literature mini-review, Rev. Sci. Eau 21(4) (2008) 413-426.

[3] M. Grunga, T. Kallqvista, S. Sakshaugb, S. Skurtveitb, K.V. Thomasa, Environmental assessment of Norwegian priority pharmaceuticals based on the EMEA guideline, Ecotox. Environ. Safe. 71 (2008) 328-340.

[4] S.A. Snyder, Occurrence, treatment, and toxicological relevance of EDCs and pharmaceuticals in water, Ozone-Sci. Eng. 30(1) (2008) 65-69.

[5] S. Mompelat, B. Le Bot, O. Thomas, Occurrence and fate of pharmaceutical products and byproducts, from resource to drinking water, Environ. Int. 35(5) (2009) 803-814.

[6] K.M. Onesios, J.T. Yu, E.J. Bouwer, Biodegradation and removal of pharmaceuticals and personal care products in treatment systems: a review, Biodegradation 20 (4) (2009) 441-466.

[7] M.F. Rahman, E.K. Yanful, S.Y. Jasim, Occurrences of endocrine disrupting compounds and pharmaceuticals in the aquatic environment and their removal from drinking water: Challenges in the context of the developing world, Desalination 248 (1-3) (2009) 578-585.

[8] M. Klavarioti, D. Mantzavinos, D. Kassinos, Removal of residual pharmaceuticals from aqueous systems by advanced oxidation processes, Environ. Int. 35 (2009) 402-417.

[9] Le Parisien 02/07/07, http://www.leparisien.fr/societe/le-paracetamol-en-tete-02-07-20072008173740.php

[10] T.A. Ternes, M. Meisenheimer, D. McDowell, F. Sacher, H.J. Brauch, B.H. Gulde, G. Preuss, U. Wilme, N.Z. Seibert, Removal of pharmaceuticals during drinking water treatment, Environ. Sci. Technol. 36 (17) (2002) 3855-3863.

[11] P. Westerhoff, Y. Yoon, S. Snyder, E. Wert, Fate of endocrine-disruptor, pharmaceutical, and personal care product chemicals during simulated drinking water treatment processes, Environ. Sci. Technol. 39 (17) (2005) 6649-6663.

[12] S.A. Snyder, S. Adham, A.M. Redding, F.S. Cannon, J. DeCarolis, J. Oppenheimer, E.C. Wert, Y. Yoon, Role of membranes and activated carbon in the removal of endocrine disruptors and pharmaceuticals, Desalination 202 (1-3) (2007) 156-181.

[13] Z.R. Yu, S. Peldszus, P.M. Huck, Adsorption characteristics of selected pharmaceuticals and an endocrine disrupting compound - naproxen, carbamazepine and nonylphenol - on activated carbon, Water Res. 42 (12) (2008) 2873-2882.

[14] I. Quesada-Peñate, C. Julcour-Lebigue, U. Jáuregui-Haza, A.M. Wilhelm, H. Delmas, Comparative adsorption of levodopa from aqueous solution on different activated carbons, Chem. Eng. J. 152 (1) (2009a) 183-188.

[15] V. Naddeo, S. Meric, D. Kassinos, V. Belgiorno, M. Guida, Fate of pharmaceuticals in contaminated urban wastewater effluent under ultrasonic irradiation, Water Res. 43(16) (2009) 4019-4027.

[16] I. Quesada-Peñate, C. Julcour-Lebigue, U. Jáuregui-Haza, A.M. Wilhelm, H. Delmas, Sonolysis of levodopa and paracetamol in aqueous solutions, Ultrason. Sonochem. 16 (5) (2009b) 610-616.

[17] E. De Bel, C. Janssen, S. De Smet, H. Van Langenhove, J. Dewulf, Sonolysis of ciprofloxacin in aqueous solution: Influence of operational parameters, Ultrason. Sonochem. 18 (1) (2010) 184189.

[18] R. Andreozzia, V. Caprioa, R. Marottaa, D. Vogna, Paracetamol oxidation from aqueous solutions by means of ozonation and $\mathrm{H}_{2} \mathrm{O}_{2} / \mathrm{UV}$ system, Water Res. 37 (2003) 993-1004.

[19] T.A. Ternes, J. Stuber, N. Herrmann, D. McDowell, A. Ried, M. Kampmann, B. Teiser, Ozonation: a tool for removal of pharmaceuticals, contrast media and musk fragrances from wastewater?, Water Res. 37 (8) (2003) 1976-1982. 
[20] S. Esplugas, D.M. Bila, L.G.T. Krause, M. Dezotti, Ozonation and advanced oxidation technologies to remove endocrine disrupting chemicals (EDCs) and pharmaceuticals and personal care products (PPCPs) in water effluents, J. Hazard. Mater. 149 (3) (2007) 631-642.

[21] I.H. Kim, H. Tanaka, T. Iwasaki, T. Takubo, T. Morioka, Y. Kato, Classification of the degradability of 30 pharmaceuticals in water with ozone, UV and $\mathrm{H}_{2} \mathrm{O}_{2}$, Water Sci. Technol. 57 (2) (2008) 195-200.

[22] Y. Zhang, J.L. Zhou, B. Ning, Photodegradation of estrone and 17 $\beta$-estradiol in water, Water Res. 41 (2007) 19-26.

[23] H. Yang, T. An, G. Li, W. Song, W.J. Cooper, H. Luo, X. Guo, Photocatalytic degradation kinetics and mechanism of environmental pharmaceuticals in aqueous suspension of $\mathrm{TiO}_{2}$ : $\mathrm{A}$ case of $\beta$-blockers, J. Hazard. Mater. 179 (2010) 834-839.

[24] L.A. Perez-Estrada, S. Malato, W. Gernjak, A. Aguera, E.M. Thurman, I. Ferrer, Photo-Fenton degradation of diclofenac: identification of main intermediates and degradation pathway, Environ. Sci. Technol. 39 (2005) 8300-8306.

[25] O. Gonzalez, C. Sans, S. Esplugas, Sulfamethoxazole abatement by photo-Fenton. Toxicity, inhibition and biodegradability assessment of intermediates, J. Hazard. Mater. 146 (3) (2007) 459464.

[26] A.G. Trovo, S.A. Santos Melo, R.F. Pupo Nogueira, Photodegradation of the pharmaceuticals amoxicillin, bezafibrate and paracetamol by the photo-Fenton process -Application to sewage treatment plant effluent, J. Photoch. Photobio. A 198 (2008) 215-220.

[27] M. Skoumal, P.L. Cabot, F. Centellas, C. Arias, R.M. Rodriguez, J.A. Garrido, E. Brillas, Mineralization of paracetamol by ozonation catalyzed with $\mathrm{Fe}^{2+}, \mathrm{Cu}^{2+}$ and UVA light, Appl. Catal. B-Environ. 66 (2006) 228-240.

[28] J. Madhavan, F. Grieser, M. Ashokkumar, Combined advanced oxidation processes for the synergistic degradation of ibuprofen in aqueous environments, J. Hazard. Mater. 178 (2010) 202208.

[29] G.T. Güyer, N.H. Ince, Degradation of diclofenac in water by homogeneous and heterogeneous sonolysis, Ultrason. Sonochem. 18 (1) (2011) 114-119.

[30] F. Stüber, J. Font, A. Fortuny, C. Bengoa, A. Eftaxias, A. Fabregat, Carbon materials and catalytic wet air oxidation of organic pollutants in wastewater, Top. Catal. 33 (1-4) (2005) 3-50.

[31] M.E. Suárez-Ojeda, F. Stüber, A. Fortuny, A. Fabregat, J. Carrera, J. Font, Catalytic wet air oxidation of substituted phenols using active carbon catalyst, Appl. Catal. B-Environ. 58 (2005) 107-116.

[32] A. Santos, P. Yustos, S. Rodriguez, F. Garcia-Ochoa, Wet oxidation of phenol, cresols and nitrophenols catalyzed by activated carbon in acid and basic media, Appl. Catal. B-Environ. 65 (2006) 269-281.

[33] A. Quintanilla, J.A. Casa, J.J. Rodriguez, Catalytic wet air oxidation of phenol with modified activated carbons and Fe/activated carbon catalysts, Appl. Catal. B-Environ. 76 (2007) 135-145.

[34] H. Delmas, A.M. Wilhelm, I. Polaert, A. Fabregat, F. Stüber, J. Font, Sequential process of adsorption and catalytic oxidation on activated carbon for (pre)treatment of water polluted by nonbiodegradable organic products, French patent FRXXBL FR 2826356 A1 20021227 (2002).

[35] I. Polaert, A.M. Wilhelm, H. Delmas, Phenol wastewater treatment by a two-step adsorptionoxidation process on activated carbon, Chem. Eng. Sci. 57(9) (2002) 1585-1590.

[36] H. Delmas, C. Creanga, C. Julcour-Lebigue, A.M. Wilhelm, AD-OX: A sequential oxidative process for water treatment- adsorption and batch CWAO regeneration of activated carbon, Chem. Eng. J. 152(1) (2009) 189-194.

[37] I. Arslan-Alaton, G. Eremektar, F. Germirli-Babuna, G. Insel, H. Selcuk, B. Ozerkan, S. Teksoy, Advanced oxidation of commercial textile biocides in aqueous solution: effects on acute toxicity and biomass inhibition, Water Sci. Technol. 52 (10-11) (2005) 309-316.

[38] A. Rubalcaba, M.E. Suárez-Ojeda, J. Carrera, J. Font, F. Stüber, C. Bengoa, A. Fortuny, A. Fabregat, Biodegradability enhancement of phenolic compounds by Hydrogen Peroxide Promoted Catalytic Wet Air Oxidation, Catal. Today 124 (2007) 191-197. 
[39] M.E. Suárez-Ojeda, A. Fabregat, F. Stüber, A. Fortuny, J. Carrera, J. Font, Catalytic wet air oxidation of substituted phenols: Temperature and pressure effect on the pollutant removal, the catalyst preservation and the biodegradability enhancement, Chem. Eng. J. 132 (2007) 105-115.

[40] D. Goi, G. Di Giorgio, I. Cimarosti, B. Lesa, G. Rossi, G. Dolcetti, Treatment of Landfill Leachate by $\mathrm{H}_{2} \mathrm{O}_{2}$ Promoted Wet Air Oxidation, Chem. Biochem. Eng. Q. 23 (3) (2009) 343-349.

[41] J. Reungoat, M. Macova, B.I. Escher, S. Carswell, J.F. Mueller, J. Keller., Removal of micropollutants and reduction of biological activity in a full scale reclamation plant using ozonation and activated carbon filtration, Water Res. 44 (2) (2010) 625-637.

[42] I. Oller, S. Malato, J.A. Sánchez-Pérez, Combination of Advanced Oxidation Processes and biological treatments for wastewater decontamination- A review, Sci. Total Environ. 409 (20) (2011) 4141-4166.

[43] H.P. Boehm, Some aspects of the surface chemistry of carbon blacks and other carbons, Carbon 32 (5) (1994) 759-769.

[44] S. Suwanprasop, A. Eftaxias, F. Stüber, I. Polaert, C. Julcour-Lebigue, H. Delmas, Scale up and modelling of fixed bed reactors for the catalytic phenol oxidation over adsorptive active carbon, Ind. Eng. Chem. Res. 44 (25) (2005) 9513-9523.

[45] R.W. Coughlin, F.S. Ezra, Role of surface acidity in the adsorption of organic pollutants on the surface of carbon, Environ. Sci. Technol. 2 (4) (1968) 291-297.

[46] M. Franz, H.A. Arafat, N.G. Pinto, Effect of chemical surface heterogeneity on the adsorption mechanism of dissolved aromatics on activated carbon, Carbon 38 (13) (2000) 1807-1819.

[47] C. Julcour Lebigue, C. Andriantsiferana, N.G. Krou, C. Ayral, E. Mohamed, A.M. Wilhelm, H. Delmas, L. Le Coq, C. Gerente, K.M. Smith, S. Pullket, G.D. Fowler, N.J.D Graham, Application of sludge-based carbonaceous materials in a hybrid water treatment process based on adsorption and catalytic wet air oxidation, J. Environ. Manage. 91 (12) (2010) 2432-2439. 


\section{List of tables}

Table 1. Physico-chemical properties of fresh ACs.

Table 2. Paracetamol adsorption, conversion and COD removal with fresh ACs

$\left(\mathrm{T}=150{ }^{\circ} \mathrm{C}, \mathrm{C}_{0}=1000 \mathrm{mg} / \mathrm{L}, \mathrm{w}_{\mathrm{cat}}=1 \mathrm{~g}, \mathrm{t}_{\text {oxidation }}=2 \mathrm{~h}\right.$ with $\left.\mathrm{P}_{\mathrm{O} 2}=3.2 \mathrm{bar}\right)$.

Table 3. Textural properties and thermogravimetric analysis of aged ACs after 5 oxidations in batch autoclave. 


\section{Figure captions}

Figure 1. AD-OX experimental set up

$\mathbf{1}$ jacketed packed bed column, $\mathbf{2}$ gas-liquid separator, $\mathbf{3}$ pressurized liquid storage tank, $\mathbf{4}$ condenser, $\mathbf{5}$ gas mass-flow controllers, $\mathbf{6}$ feed tank, $\mathbf{7}$ balance, $\mathbf{8}$ dosing pump, $\mathbf{9}$ sampling device, $\mathbf{1 0}$ liquid sample valves, 11 pneumatic valve, 12 expansion vase, 13 gear pump, 14 heater, 15 cooling exchanger, 16* cooling exchanger, 17* anti-pulsatory vessel, 18* flowmeter, V1-V5 three-way valves for up- or down-flow mode.

Figure 2. Adsorption isotherms of paracetamol on L27, S23 and C1 carbons at $25^{\circ} \mathrm{C}$.

Figure 3. Batch adsorption and CWAO of paracetamol on fresh ACs

$\left(\mathrm{T}=150^{\circ} \mathrm{C}, \mathrm{C}_{0}=1000 \mathrm{mg} / \mathrm{L}, \mathrm{w}_{\mathrm{ac}}=1 \mathrm{~g}\right.$, adsorption: $\mathrm{P}_{\mathrm{N} 2}=10$ bar, oxidation: $\mathrm{P}_{\mathrm{O} 2}=3.2$ bar $)$.

Figure 4. Evolution of (a) paracetamol conversion and (b) COD removal, using recycled ACs $\left(\mathrm{T}=150^{\circ} \mathrm{C}, \mathrm{C}_{0}=1000 \mathrm{mg} / \mathrm{L}, \mathrm{w}_{\mathrm{ac}}=1 \mathrm{~g}, \mathrm{t}_{\text {oxidation }}=2 \mathrm{~h}\right.$ with $\left.\mathrm{P}_{\mathrm{O} 2}=3.2 \mathrm{bar}\right)$.

Figure 5. OUR profiles obtained with (a) $50 \mathrm{mg} / \mathrm{L}$ paracetamol solution, before batch oxidation; (b) effluent resulting from catalytic oxidation of paracetamol on $\mathrm{L} 27$.

Figure 6. Adsorbed amount of paracetamol on recycled ACs.

Figure 7. Successive breakthrough curves on $\mathbf{L} 27\left(\mathrm{C}_{\mathrm{in}}=1 \mathrm{~g} / \mathrm{L}, \mathrm{Q}_{\mathrm{L}}=6.5 \mathrm{~L} / \mathrm{h}, \mathrm{w}_{\mathrm{ac}}=168 \mathrm{~g}, \mathrm{~T}=25^{\circ} \mathrm{C}\right)$.

Figure 8. Successive breakthrough curves on $\mathbf{S 2 3}\left(\mathrm{C}_{\mathrm{in}}=2 \mathrm{~g} / \mathrm{L}, \mathrm{Q}_{\mathrm{L}}=6.5 \mathrm{~L} / \mathrm{h}, \mathrm{w}_{\mathrm{AC}}=340 \mathrm{~g}, \mathrm{~T}=25^{\circ} \mathrm{C}\right)$.

Figure 9. Evolution of concentration profiles during the first oxidation $\left(\mathrm{T}=150^{\circ} \mathrm{C}, \mathrm{P}_{\mathrm{O} 2}=3.2 \mathrm{bar}, \mathrm{Q}_{\mathrm{L}}=2 \mathrm{~L} / \mathrm{h}\right.$ (recycle), $\left.\mathrm{Q}_{\mathrm{G}}=100 \mathrm{~L} / \mathrm{h} \mathrm{STP}, \mathrm{C}_{0},_{\mathrm{ox}}=3753 \mathrm{mg} / \mathrm{L}(\mathrm{L} 27) / 5884 \mathrm{mg} / \mathrm{L}(\mathrm{S} 23), \mathrm{V}_{\mathrm{L}}=2 \mathrm{~L}\right)$ : (a) normalized concentration of paracetamol, (b) chemical oxygen demand. 
Table 1

\begin{tabular}{|c|c|c|c|}
\hline $\mathrm{AC}$ & L27 & S23 & $\mathrm{C} 1$ \\
\hline BET surface area, $\mathrm{m}^{2} / \mathrm{g}$ & 1860 & 1180 & 1230 \\
\hline Microporous volume, $\mathrm{cm}^{3} / \mathrm{g}$ & 0.77 & 0.47 & 0.53 \\
\hline Mesoporous volume, $\mathrm{cm}^{3} / \mathrm{g}$ & 0.48 & 0.05 & 0.26 \\
\hline Mesoporous/microporous volume ratio & 0.62 & 0.11 & 0.49 \\
\hline Average pore diameter, $\AA$ & 25 & 17 & 22 \\
\hline Apparent density (g/L) & 552 & 1024 & 799 \\
\hline Acid groups, $\mathrm{mmol} / \mathrm{g}$ & 1.85 & 0.30 & 0.12 \\
\hline Basic groups, $\mathrm{mmol} / \mathrm{g}$ & 0.59 & 0.98 & 2.13 \\
\hline Total surface groups, $\mathrm{mmol} / \mathrm{g}$ & 2.44 & 1.28 & 2.25 \\
\hline $\mathrm{pH}_{\mathrm{PZC}}$ & 6.2 & 9.7 & 11 \\
\hline \%weight loss between 200 and $700^{\circ} \mathrm{C}$ & 16.0 & 4.2 & 6.6 \\
\hline$\% \mathrm{C}$ & 71.1 & 92.3 & 86.5 \\
\hline$\% \mathrm{H}$ & 2.5 & 0.6 & 0.8 \\
\hline$\% \mathrm{~N}$ & 0.3 & 0.3 & 0.3 \\
\hline$\% \mathrm{O}$ & 19.3 & 2.3 & 3.4 \\
\hline$\%$ Ash & 8.3 & 3.2 & n.a. \\
\hline$\% \mathrm{Fe}$ & 0.008 & 0.012 & 0.064 \\
\hline$\% \mathrm{Cu}$ & 0.011 & 0.007 & 0.005 \\
\hline
\end{tabular}


Table 2

\begin{tabular}{|c|c|c|c|}
\hline $\mathrm{CA}$ & $\begin{array}{c}\mathrm{q}_{\mathrm{e}} \\
\left(\mathrm{mg} / \mathrm{g}_{\mathrm{AC}}\right)\end{array}$ & $\begin{array}{c}\text { Paracetamol conversion } \\
(\%)\end{array}$ & $\begin{array}{c}\text { COD removal }^{*} \\
(\%)\end{array}$ \\
\hline $\mathrm{L} 27$ & $87 \pm 2$ & $89 \pm 1$ & $41 \pm 0.6$ \\
\hline $\mathrm{S} 23$ & 135 & 95 & 60 \\
\hline $\mathrm{C} 1$ & $126 \pm 4$ & $98 \pm 0$ & $62 \pm 8$ \\
\hline
\end{tabular}

*calculated from initial and final concentrations (respectively COD values) of oxidation step 
Table 3

\begin{tabular}{|c|c|c|c|c|c|c|}
\hline $\mathrm{AC}$ & $\begin{array}{c}\text { BET } \\
\text { surface } \\
\text { area, } \mathrm{m}^{2} / \mathrm{g}\end{array}$ & $\begin{array}{c}\text { Microporous } \\
\text { volume, } \\
\mathrm{cm}^{3} / \mathrm{g}\end{array}$ & $\begin{array}{c}\text { Mesoporous } \\
\text { volume, } \\
\mathrm{cm}^{3} / \mathrm{g}\end{array}$ & $\begin{array}{c}\text { Mesoporous/microporous } \\
\text { volume ratio, - }\end{array}$ & $\begin{array}{l}\text { Average pore } \\
\text { diameter, } \AA\end{array}$ & $\begin{array}{c}\text { \%weight loss } \\
\text { between } 200 \text { and } \\
700^{\circ} \mathrm{C}\end{array}$ \\
\hline L27 & 560 & 0.23 & 0.04 & 0.17 & 18 & 28.2 \\
\hline $\mathrm{S} 23$ & 45 & 0.02 & 0.006 & 0.30 & 21 & 12.4 \\
\hline$\overline{\mathrm{C} 1}$ & 85 & 0.04 & 0.09 & 2.3 & 46 & 16.0 \\
\hline
\end{tabular}




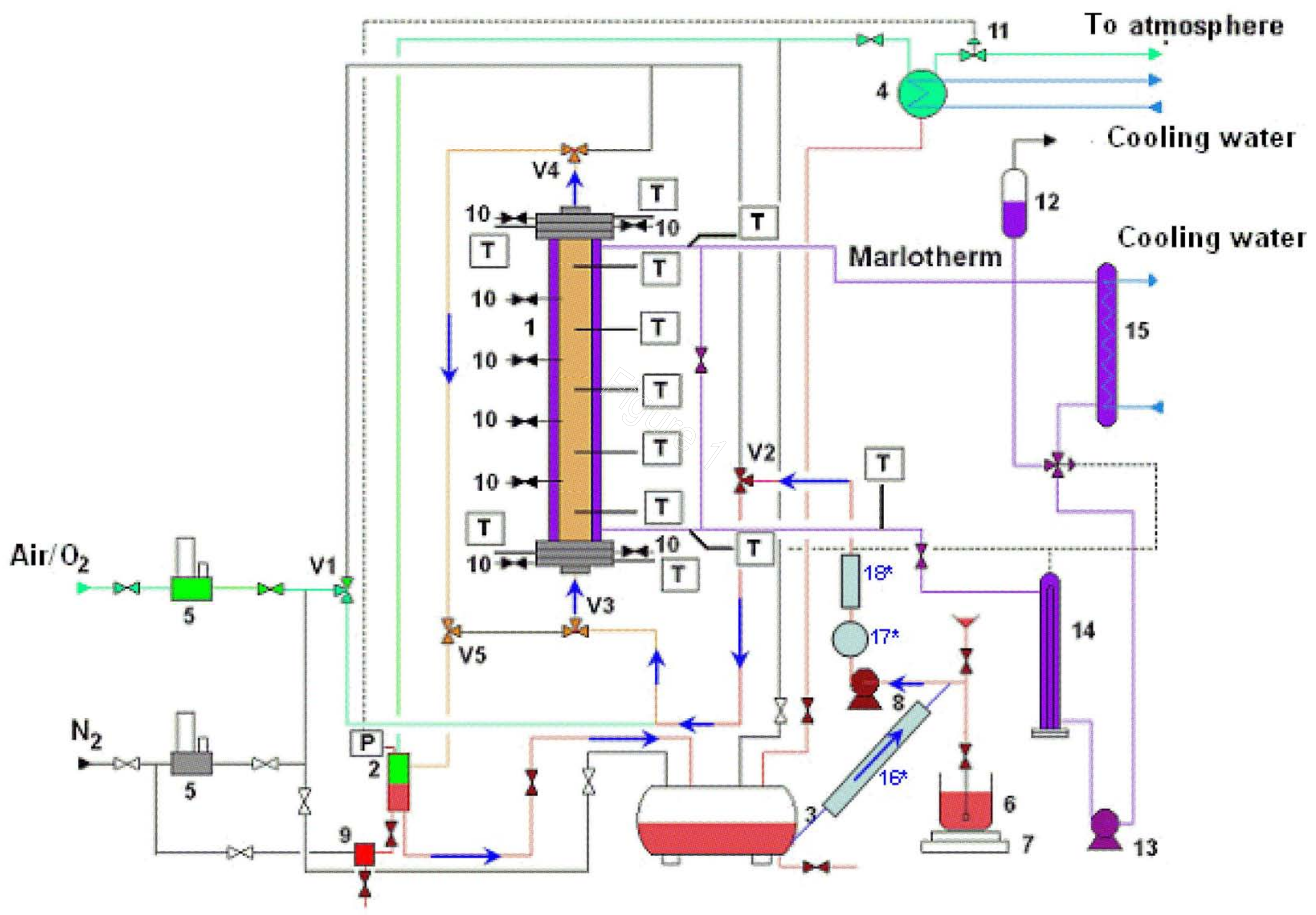




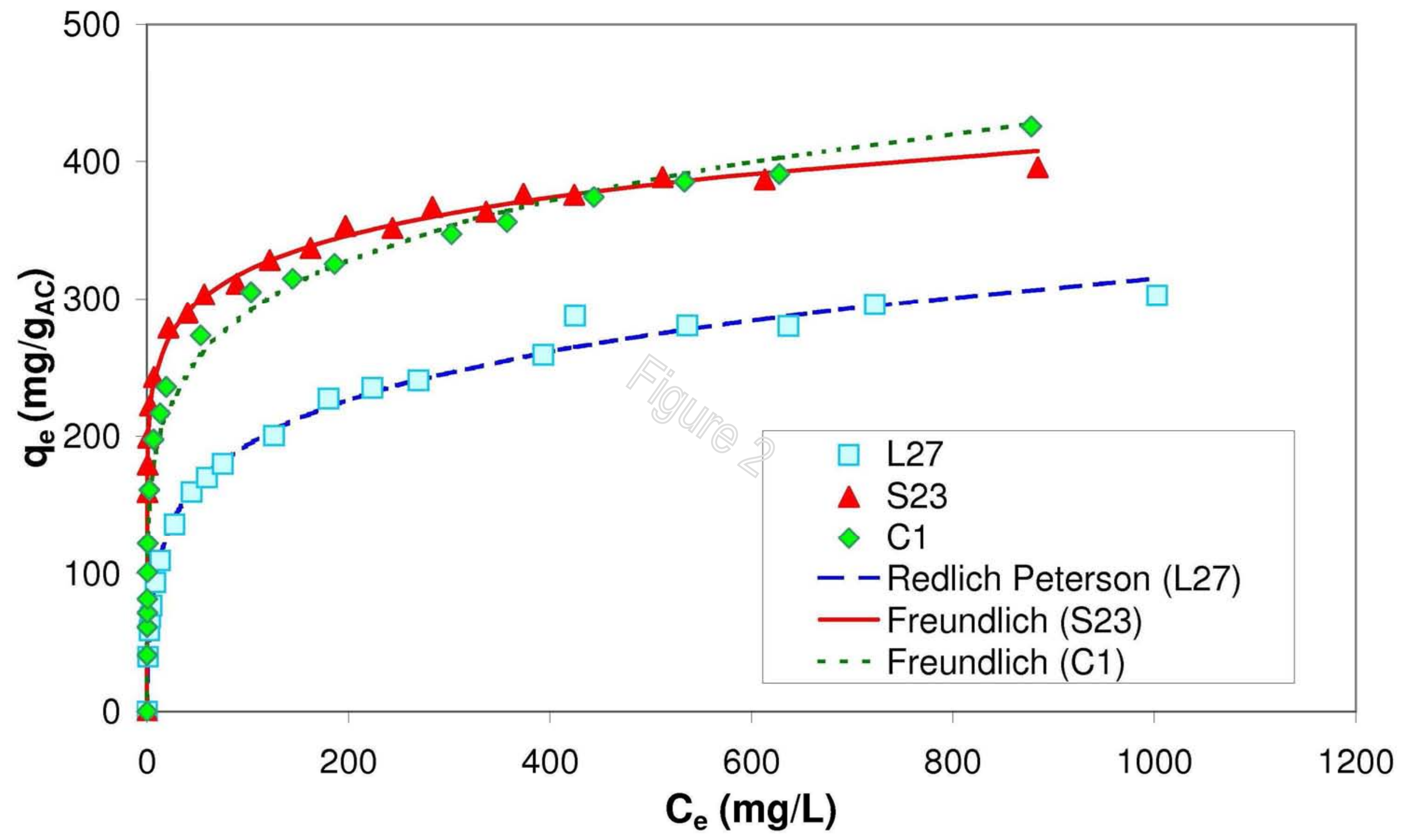




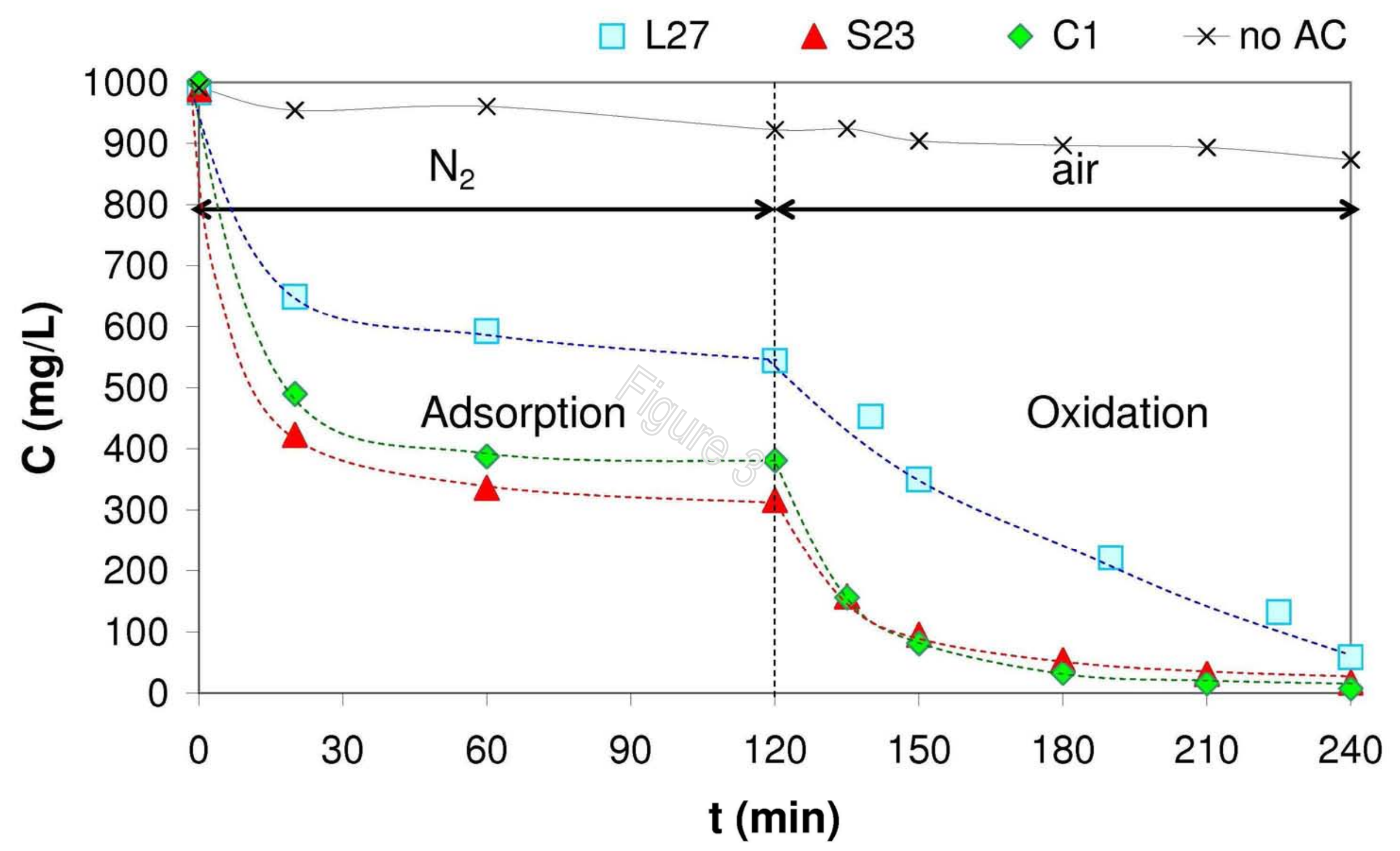




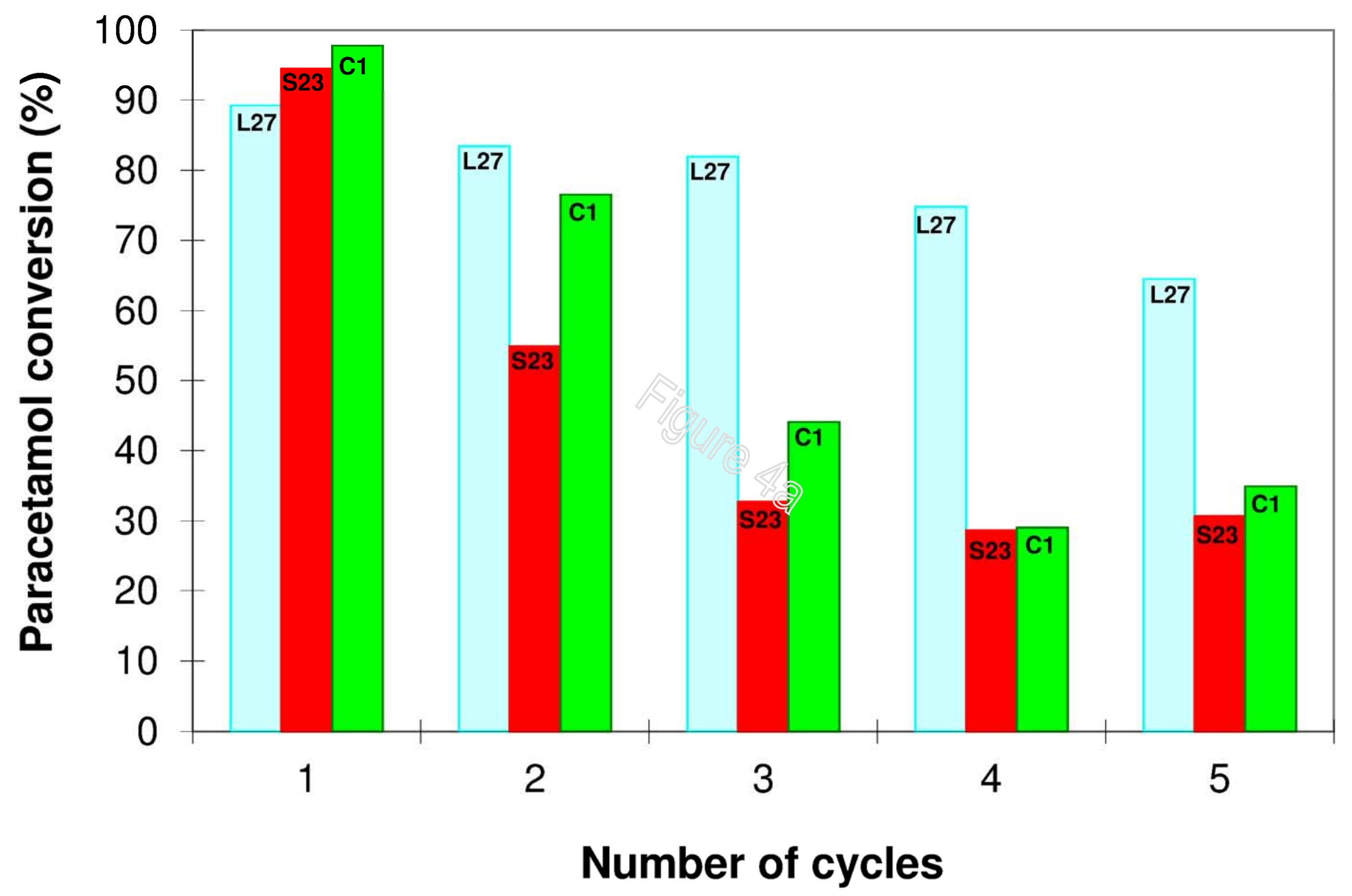




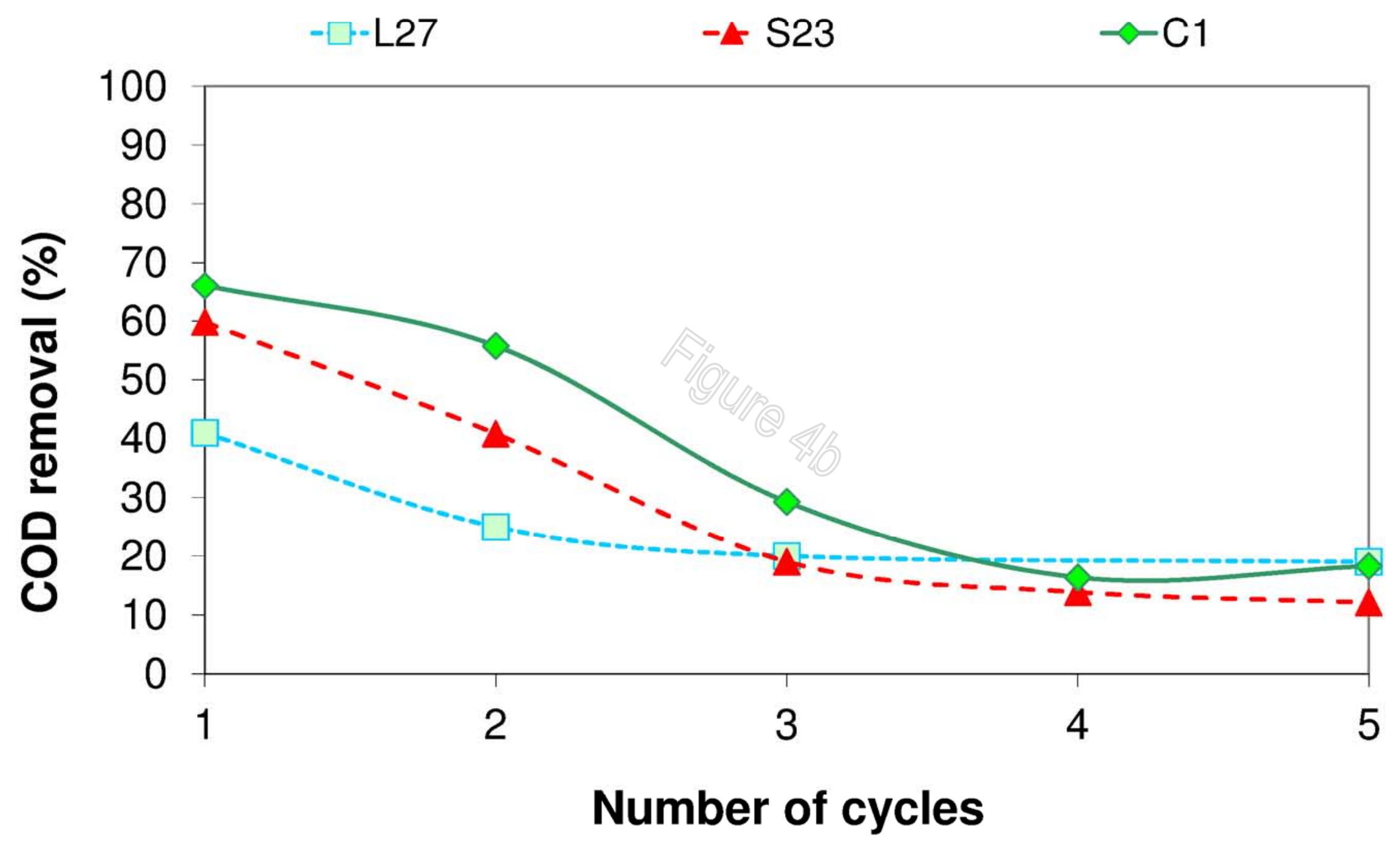




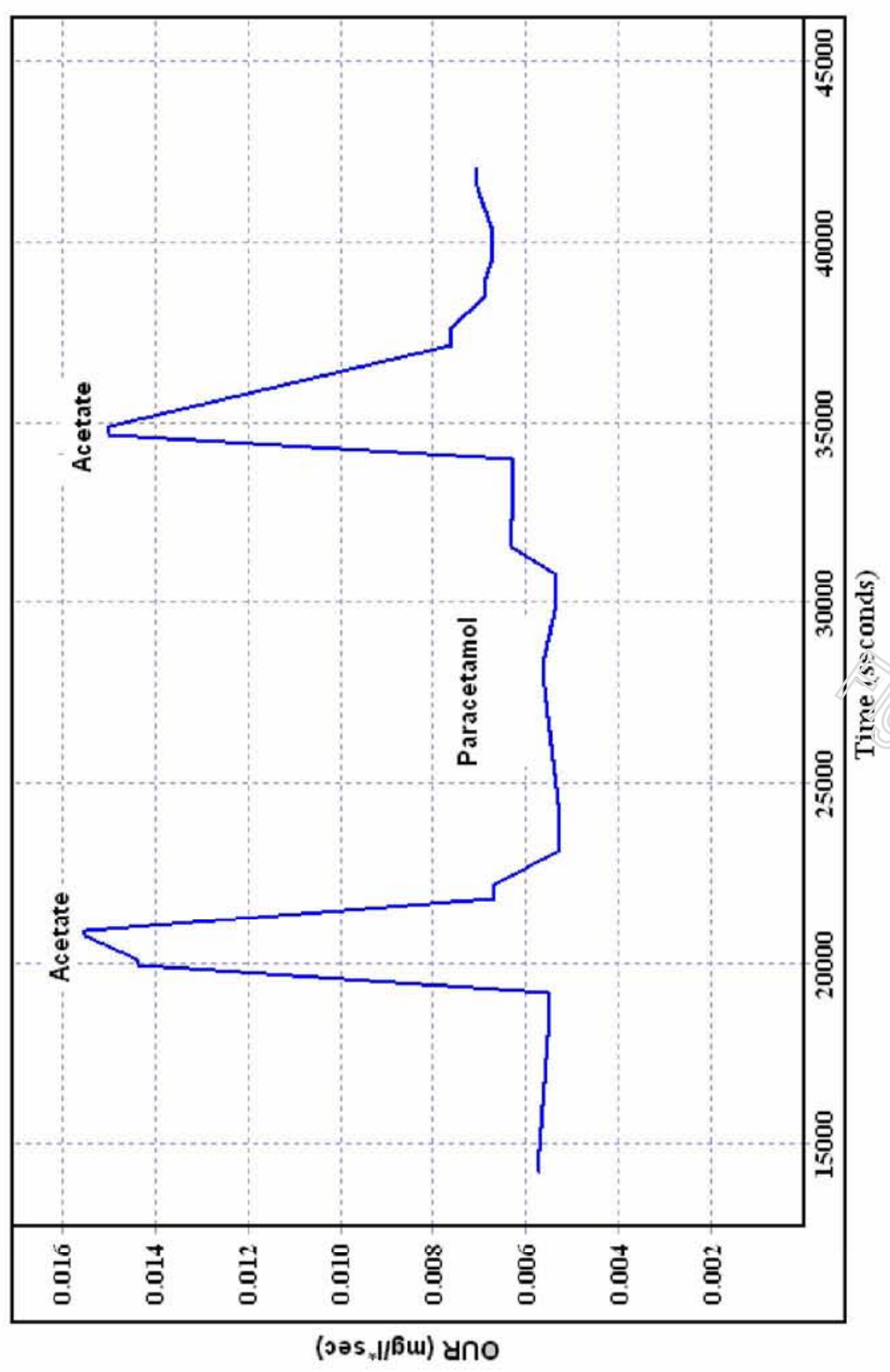




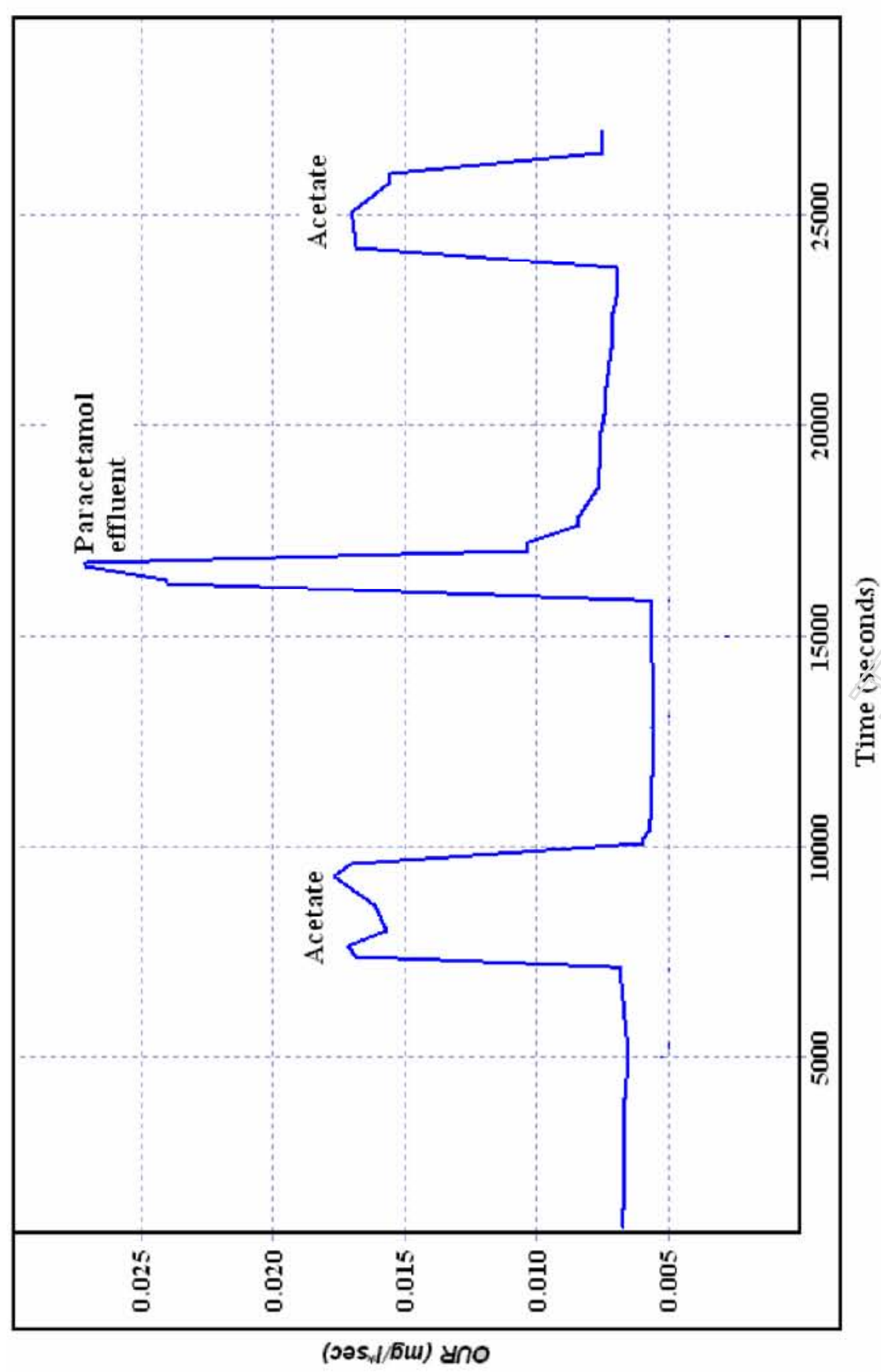




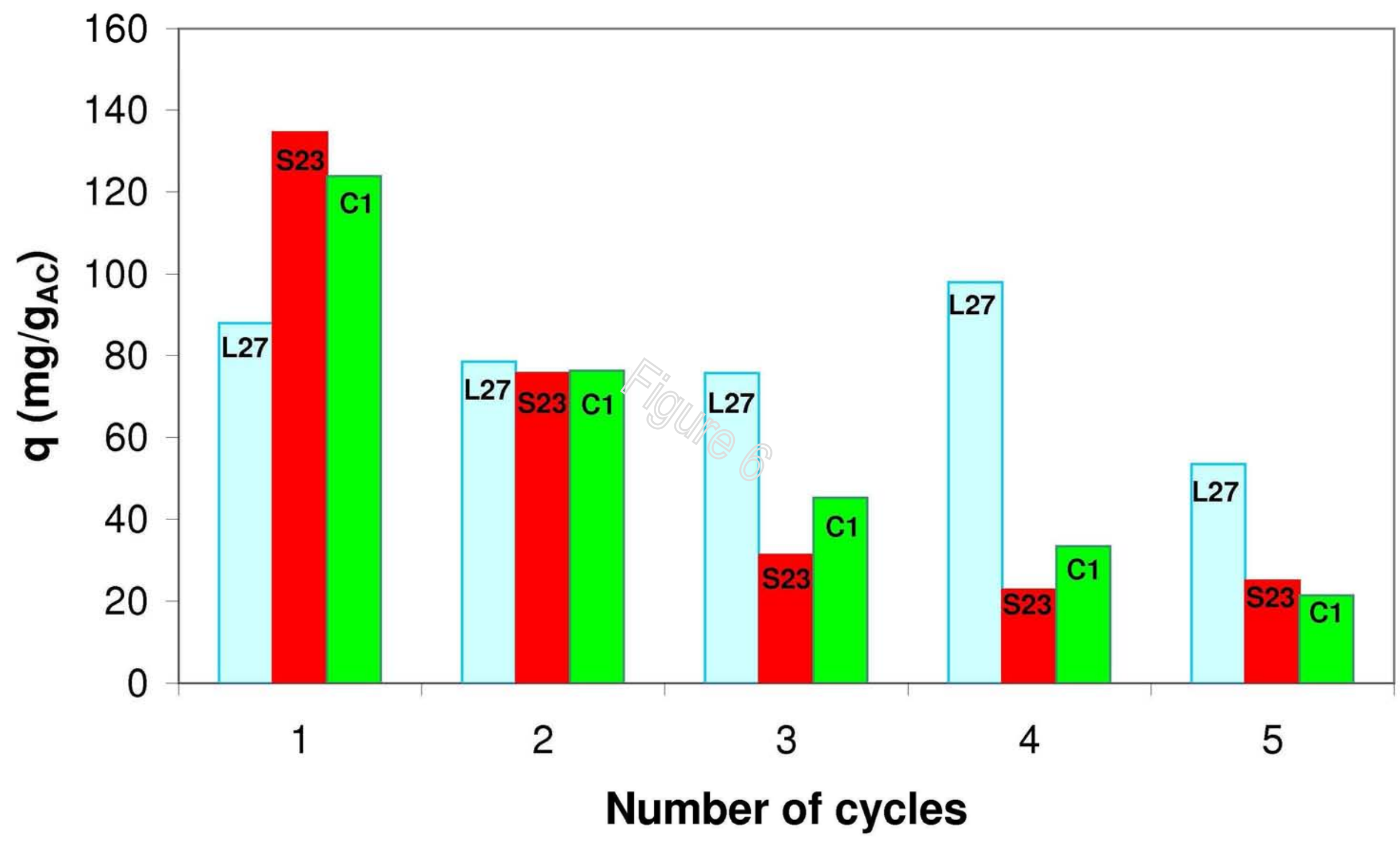




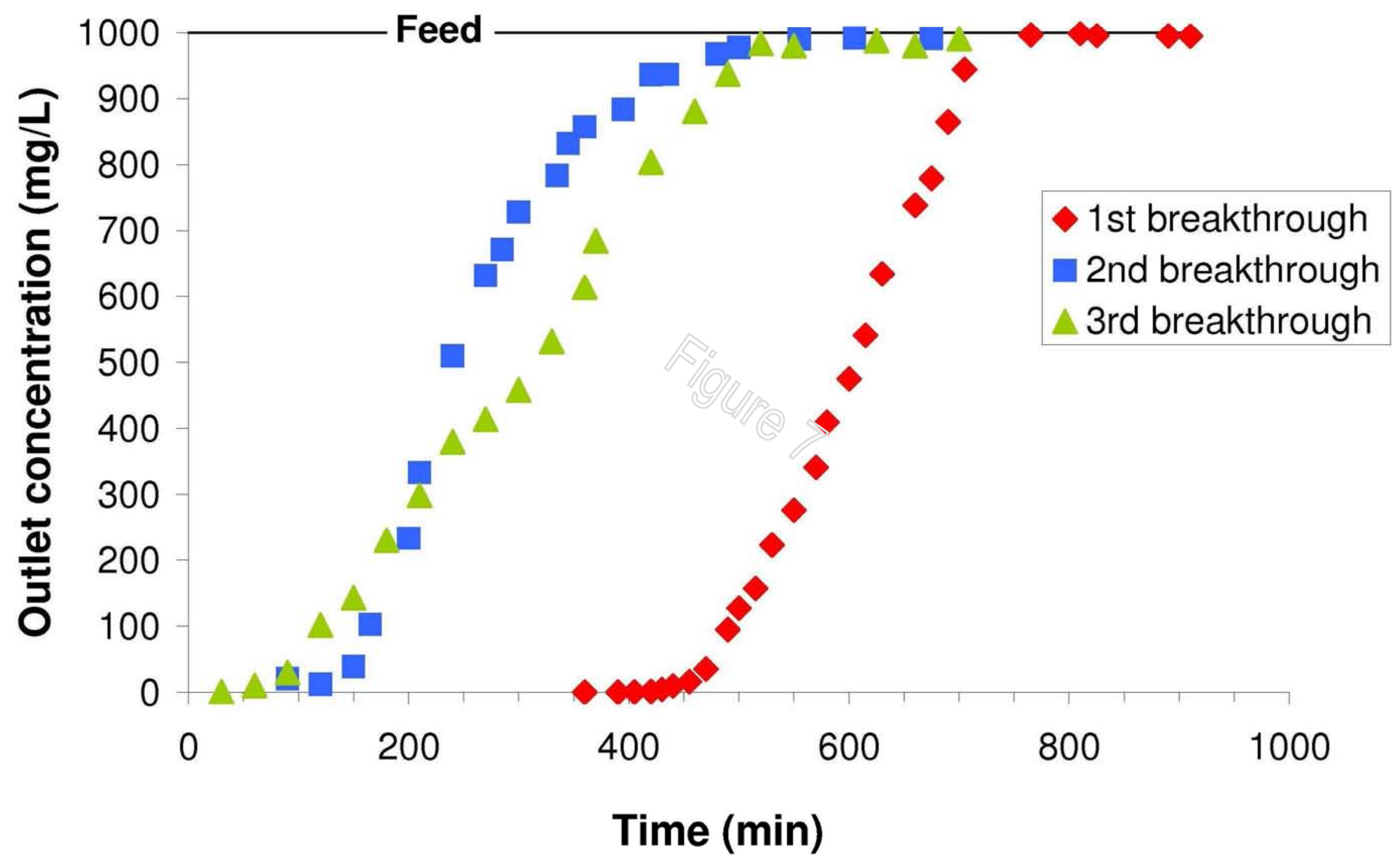




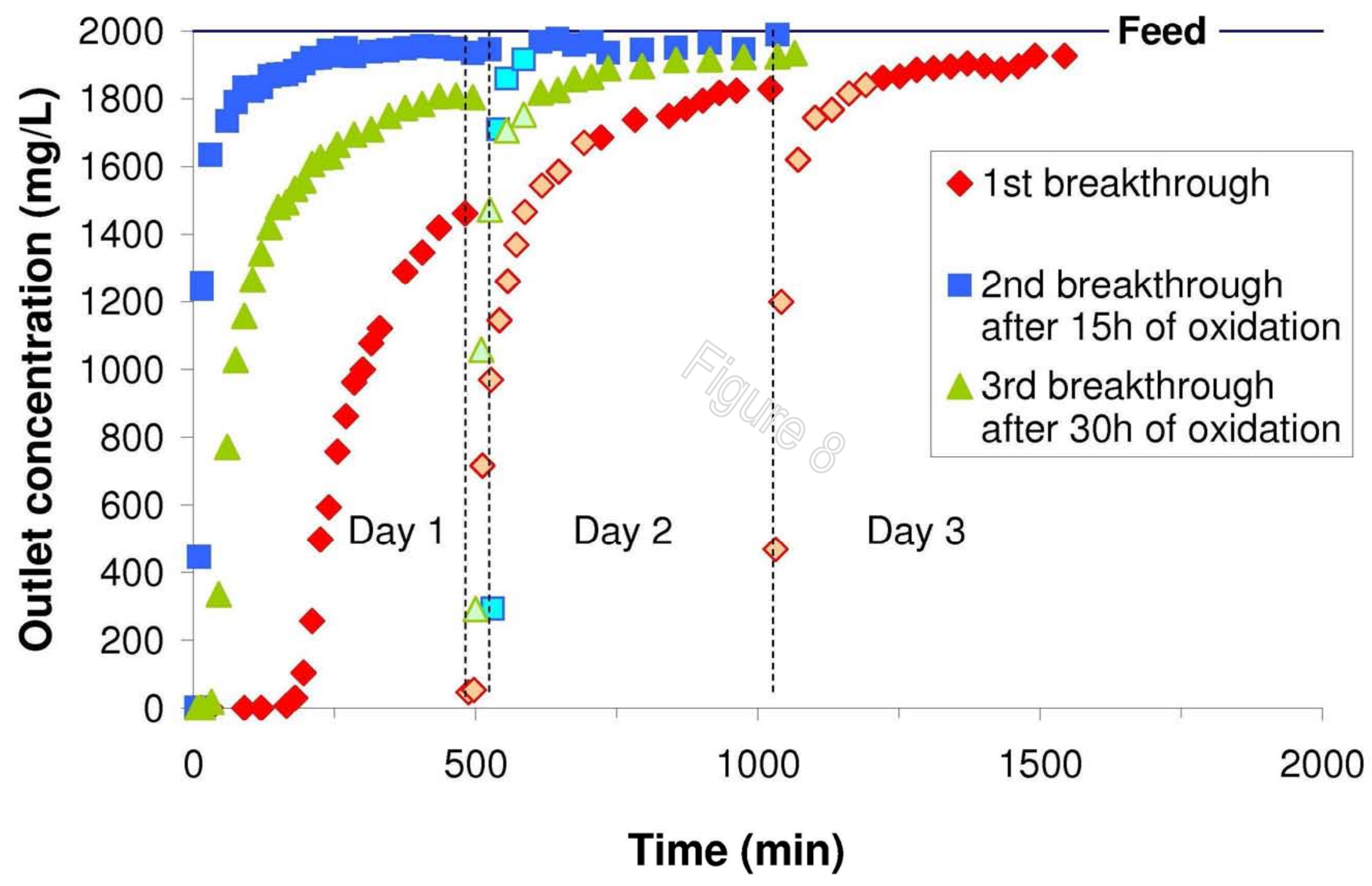




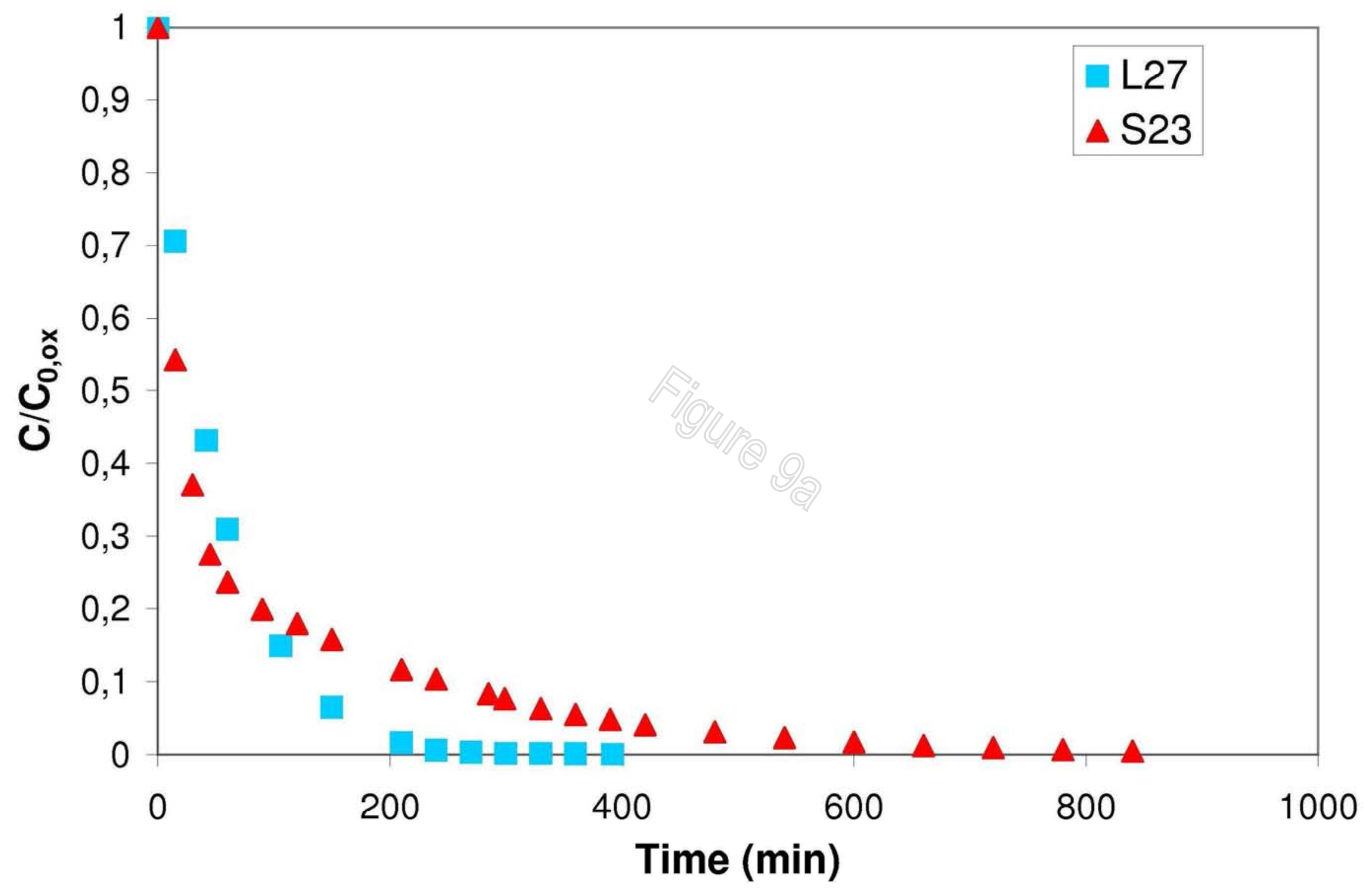




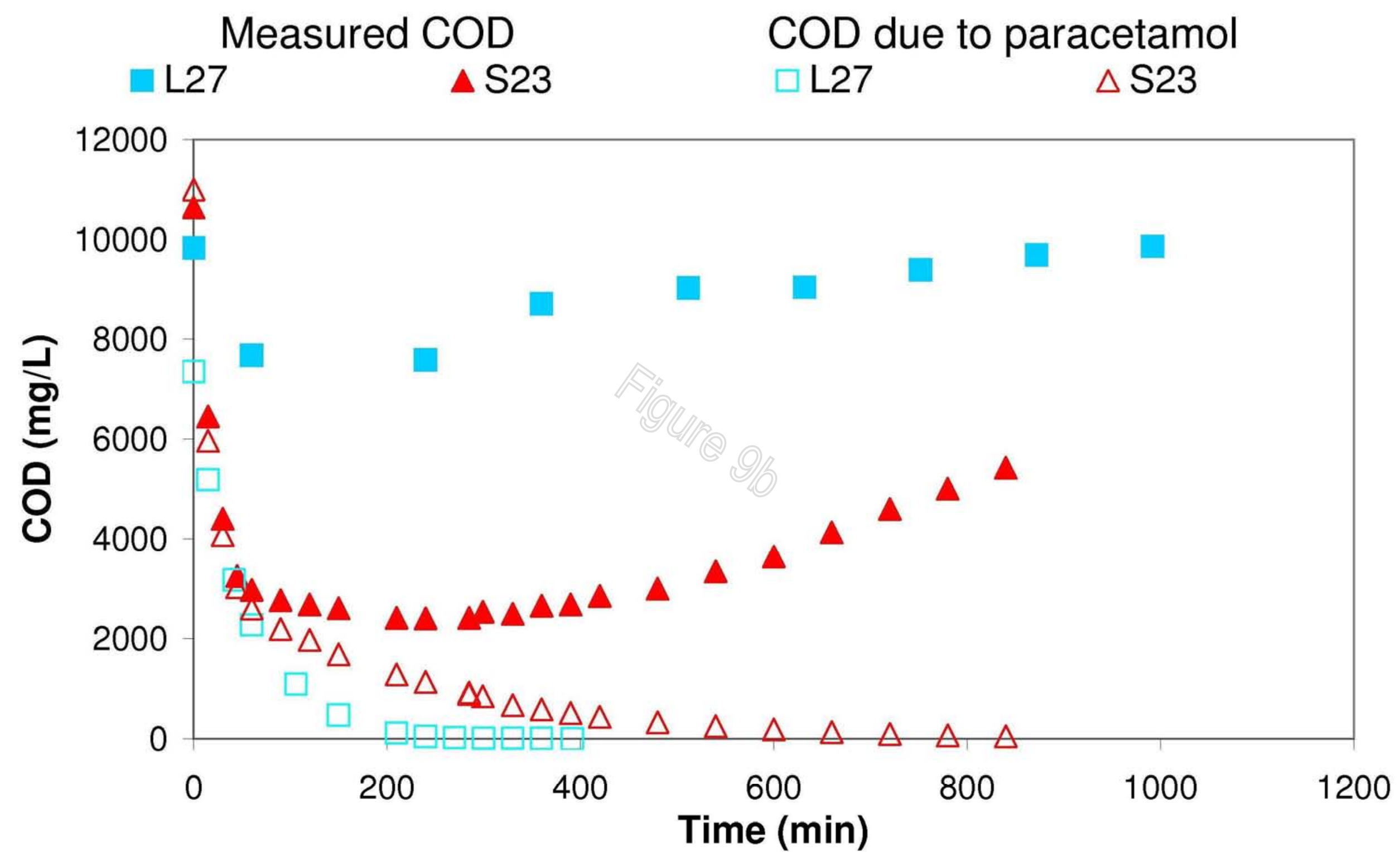

